\section{Acidification of soil and water}

VAN BREEMEN et al. ${ }^{1}$ narrowly and arbitrarily define acidification of soil as the 'loss of bases' or 'decrease in acidneutralizing capacity', the rate of which can be equated with the rate of mineral weathering ${ }^{2}$. However, any definition of soil acidification should include the obvious fact that it also involves the 'accumulation of acids', that is, an increase in 'base-neutralizing capacity'. Although the authors consider the base-neutralizing capacity of water, they do not do so for soils ${ }^{1}$. By ignoring soil acidity they conclude that cation exchange reactions play no part in acidification ${ }^{1}$, whereas in fact they $\mathrm{do}^{3}$.

The authors' statement that enough is now known to compare external and internal sources of acidity ${ }^{1}$ is not supported by the material they present. Estimates of socalled hydrogen-ion budgets are highly data intensive and require an extraordinary amount of effort to develop ${ }^{4}$. Not surprisingly, critical examination of the references cited by the authors and used to develop such budgets, as in Table 2 of ref. 1 , shows that for many of the sites the data are seriously incomplete. Even in those cases where the data are complete enough to develop a hydrogen-ion budget, as at Hubbard Brook, the budget is of net transformations that occur throughout a year. Driscoll et al. have stated ${ }^{5}$ that "[hydrogen-ion budget] in no way attempts to quantify the gross hydrogen-ion transformations within the ecosystem" and "it is virtually impossible to quantify all of the individual, internal cycling of elements that occur within an ecosystem". Accordingly, total proton sources and sinks have not been categorized, contrary to statements of van Breemen et al. ${ }^{1}$. Their data are biased towards overestimating the relative extent and rate of acidification by acidic deposition.

Regions of eastern North America and northern Europe, where there is great concern about acidification, are characterized by the pronounced accumulation of acid organic matter ${ }^{2}$. The role of organic acids is not simply one of cation exchange (or weathering), as asserted by van Breemen et al. ${ }^{1}$, but also involves complexation and solubilization ${ }^{2}$. Some organic complexes and acids normally soluble in 'clean' environments are immobilized by the strong acids in rain ${ }^{2,6}$. This compensating shift in internal cycling of elements and acids is not accommodated by hydrogenion budgets derived from net transformations.

\section{E. C. KRUG}

\section{The Connecticut Agricultural}

Experiment Station,

New Haven, Connecticut 06504, USA
1. Van Breemen, N., Driscoll, C. T. \& Mulder, J. Nature 307, 599-604 (1984).

2. Krug, E. C. \& Frink, C. R. Science 221, 520-525 (1983). 3. Overrein, L. N., Seip, H. M. \& Tollan, A. (eds) SNSF Project Res. Rep. FR19/80 (1980).

4. Galloway, J. N., Norton, S. A. \& Church, M. R. Envir. Sci Technol. 17, 541 A-545A (1983).

5. Driscoll, C. T. \& Likens, G. E. Tellus 34, 283-292 (1982). 6. Krug, E. C. \& Isaacson, P. J. Soil Sci. 137, 370-378 (1984)

VAN BREEMEN ETAL. REPLY-Accumulation of organic matter does increase the base neutralizing capacity of soils and could be considered as soil acidification. However, changes in organic base neutralizing capacity (which is determined using strong base or a concentrated salt solution) are irrelevant to the proton loading of soils and waters under ambient conditions, where only a very small part of the organic base neutralizing capacity is realized by dissociation of $\mathrm{H}^{+}$. Hydrogenion budgets ${ }^{1-3}$ do, in fact, account for two major processes of $\mathrm{H}^{+}$dissociation in organic matter: (1) the displacement of $\mathrm{H}^{+}$from organic matter by atmospherically deposited cations

$$
\begin{aligned}
& \mathrm{MCl}_{\text {atm }}+\mathrm{H} \text {-org } \\
& \quad \mathrm{\text {soil }} \rightarrow \\
& \text {-org } \\
& \text { soil } \\
& +\mathrm{HCl}_{\text {drainwater }}
\end{aligned}
$$

and (2) the dissolution and deprotonation of organic acids followed by leaching

$$
\begin{array}{r}
\text { H-org } \\
\text { soil solution } \\
\text { H-soil }+ \text { M-soil } \rightarrow \\
\rightarrow \text {-org drainwater }
\end{array}
$$

$\mathrm{H}^{+}$budgets show that net $\mathrm{H}^{+}$fluxes, due to organic acids, are zero (equation 1 ) or relatively small (equation 2), even in podzolic and peat soils ${ }^{3}$. For example, Hubbard Brook Experimental Forest stream water $^{4}$ is dominated by $\mathrm{SO}_{4}^{2-}$ (122.4 $\mu$ equiv. $1^{-1}$ out of $166.5 \mu$ equiv. $1^{-1}$ of total anionic charge) largely of atmospheric origin, whereas aqueous acidity $\left(\mathrm{H}^{+}+\mathrm{Al}^{\mathrm{n}+}=35\right.$ uequiv. $\left.1^{-1}\right)$ far exceeds organic anions $\left(<2 \mu\right.$ equiv. $\left.1^{-1}\right)$, showing that atmospheric inputs, not organic acids, cause acidification of stream water.

Proton release, at a $p \mathrm{H}$ below the reference value (for example, $p \mathrm{H} 4.5$ for forest soils), by complexation of soil metals with organic matter, without drainage export, is ignored in our $\mathrm{H}^{+}$budget, and should indeed be considered as soil acidification:

$$
\mathrm{H} \text {-org } \text { soil }+\mathrm{M} \text {-soil } \rightarrow \mathrm{H} \text {-soil }+ \text { M-org } \text { soil }
$$

The only important process of this kind is the accumulation of $\mathrm{Al}$ and $\mathrm{Fe}$ organic complexes in podzols. Data on Hubbard Brook soils ${ }^{5}$, and titration curves for $\mathrm{H}^{+}$. saturated organic matter from podzol-B horizons $^{6,7}$, reveal that this process contributes little $\left(0.005-0.01 \mathrm{kmol}^{\text {hectare }}{ }^{-1}\right.$ $\left.\mathrm{yr}^{-1}\right)$ to present acidification of podzolic soils (1-2 kmol hectare $\left.\mathrm{kr}^{-1} \mathrm{yr}^{-1}\right)$.

Total proton sources and sinks refer to summed net $\mathrm{H}^{+}$sources and sinks for various categories of processes. It is these net $\mathrm{H}^{+}$fluxes, and not gross $\mathrm{H}^{+}$transformations, which define the sign and magnitude of the irreversible $\mathrm{H}^{+}$flux constituting soil acidification or soil alkalinization.
In conclusion, $\mathrm{H}^{+}$budgets account for essentially all processes relevant to soil acidification. Concern about acidification by organic matter ${ }^{8,9}$ probably originates from the concepts of soil acidity and lime requirement. These concepts are important when raising the $p \mathrm{H}$ of an acidic, highly organic soil for crop production, but are of little significance when comparing internal and external proton sources in ecosystems.

\[ \text { N. VAN BREEMEN* } \]
C. T. DRISCOLL $\dagger$
J. MULDER*
* Department of Soil Science
and Geology,
Agricultural University,
6700 AA Wageningen,
The Netherlands
$\dagger$ Department 0 Civil Engineering,
Syracuse University, Syracuse,
New York 13210, USA

1. Driscoll, C. T. \& Likens, G. E. Tellus 34, 283-292 (1982). 2. van Breemen, N., Mulder, J. \& Driscoll, C. T. PL. Soil 75, 283-308 (1983).

3. van Breemen, N., Driscoll, C. T. \& Mulder, J. Nature 307, 599-604 (1984).

4. Likens, G. E., Bormann, F. H., Pierce, R. S., Eaton, J. S. \& Johnson, N. M. Biogeochemistry of a Forested Ecosystem (Springer, New York, 1977).

5. Driscoll, C. T., van Breemen, N. \& Mulder, J. J. Soil Sci. Soc. Am. (in the press).

6. Martin, A. E. \& Reeve, R. J. Soil Sci. 9, 89-100 (1958)

7. Hargrove, W. L. \& Thomas, G. W. Soil Sci. 134, 216-225 (1982)

8. Krug, E. C. \& Frink, C. R. Science 221, 520-525 (1983)

9. Rosenqvist, I. T. Sci. Total Envir. 10, 271-272 (1978).

\section{Phonetic analysis capacity and learning to read}

BRADLEY and Bryant's ${ }^{1}$ result showing that training children on sound classification and letter-sound correspondences improves their later reading performance is clearly an important one. It brings definite support to methods of reading instruction that disclose explicitly the principle of the alphabetic code. The authors might have stressed that aspect of their findings, rather than the effect obtained with the group trained solely on sound classification, which fell short of significance.

The phrasing of the authors' conclusion that the connection of reading acquisition to phonological awareness is a causal one is unfortunate, however. If 'causal' means a link that runs one way only, the implication is to deny the possibility of the inverse type of relation. There is evidence, in fact, that learning to read improves understanding of the phonological structure of speech and hence ability to manipulate it at the level of phonetic segments. We have found, for example, that first grade (6-yrold) children taught by a look-say method performed more poorly on the task of interverting initial and final phonemes of an utterance than children taught by a phonic method ${ }^{2}$. Groups of first grade children equated for age at testing time 